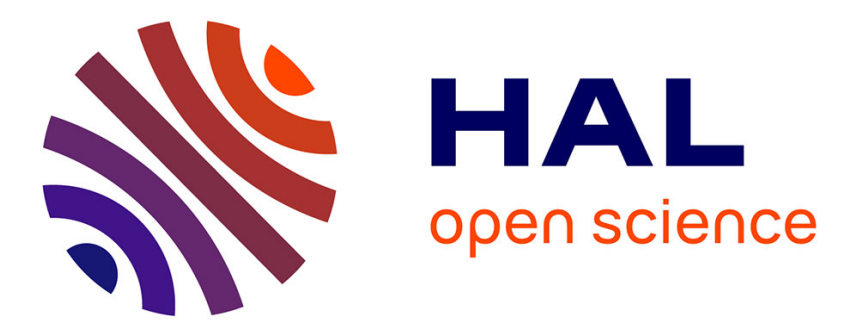

\title{
The Social Representation of the Yellow Vests Among Young French People: An Explanatory Study
}

Sandrine Gaymard, Mathieu Desgré, Nino Peulens, Alexis Frappier, Quentin Lecomte, Charlotte Lenoir, Zhe Wang

\section{To cite this version:}

Sandrine Gaymard, Mathieu Desgré, Nino Peulens, Alexis Frappier, Quentin Lecomte, et al.. The Social Representation of the Yellow Vests Among Young French People: An Explanatory Study. Journal of Social and Political Sciences, 2019, 2 (2), pp.305 - 312. 10.31014/aior.1991.02.02.71. hal-02357432

\author{
HAL Id: hal-02357432 \\ https://univ-angers.hal.science/hal-02357432
}

Submitted on 10 Nov 2019

HAL is a multi-disciplinary open access archive for the deposit and dissemination of scientific research documents, whether they are published or not. The documents may come from teaching and research institutions in France or abroad, or from public or private research centers.
L'archive ouverte pluridisciplinaire HAL, est destinée au dépôt et à la diffusion de documents scientifiques de niveau recherche, publiés ou non, émanant des établissements d'enseignement et de recherche français ou étrangers, des laboratoires publics ou privés.

\section{(c)(1)}

Distributed under a Creative Commons Attribution| 4.0 International License 


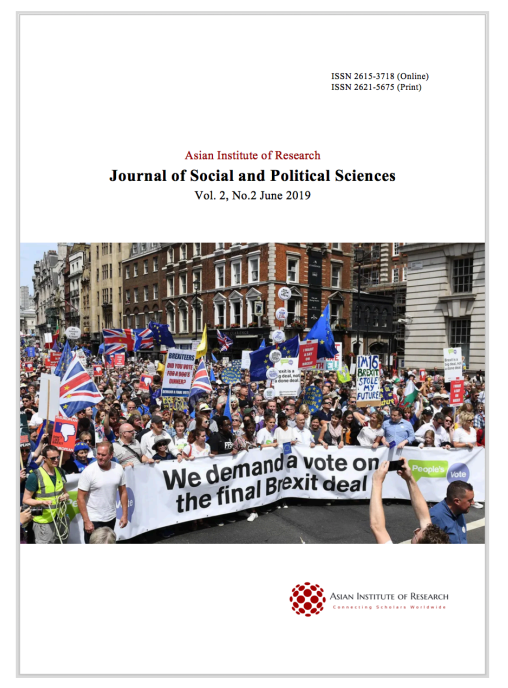

\section{Journal of Social and Political Sciences}

Gaymard, Sandrine, Desgré, Mathieu, Peulens, Nino, Frappier, Alexis, Lecomte, Quentin, Lenoir, Charlotte, and Wang, Zhe. (2019), The Social Representation of the Yellow Vests Among Young French People: An Exploratory Study. In: Journal of Social and Political Sciences, Vol.2, No.2, 305-312.

ISSN 2615-3718

DOI: 10.31014/aior.1991.02.02.71

The online version of this article can be found at: https://www.asianinstituteofresearch.org/

Published by:

The Asian Institute of Research

The Journal of Social and Political Sciences is an Open Access publication. It may be read, copied and distributed free of charge according to the conditions of the Creative Commons Attribution 4.0 International license.

The Asian Institute of Research Social and Political Sciences is a peer-reviewed International Journal. The journal covers scholarly articles in the fields of Social and Political Sciences, which includes, but not limited to, Anthropology, Government Studies, Political Sciences, Sociology, International Relations, Public Administration, History, Philosophy, Arts, Education, Linguistics, and Cultural Studies. As the journal is Open Access, it ensures high visibility and the increase of citations for all research articles published. The Journal of Social and Political Sciences aims to facilitate scholarly work on recent theoretical and practical aspects of Social and Political Sciences. 


\title{
The Social Representation of the Yellow Vests Among Young French People: An Exploratory Study
}

\author{
Sandrine Gaymard ${ }^{1}$, Mathieu Desgré ${ }^{1}$, Nino Peulens ${ }^{1}$, Alexis Frappier ${ }^{1}$, Quentin Lecomte ${ }^{1}$, Charlotte Lenoir ${ }^{1} \&$ \\ Zhe Wang ${ }^{1}$
}

\author{
${ }^{1}$ University of Angers, Laboratoire de Psychologie des Pays de la Loire (LPPL, EA 4638). SFR Confluences, \\ Univ Angers-Univ Nantes. France
}

Corresponding Author: Sandrine Gaymard, Laboratoire de Psychologie des Pays de la Loire, Université d'Angers, Maison de la recherche Germaine Tillion, 5 bis Boulevard Lavoisier, 49045 Angers Cedex 01, FranceE-mail: Sandrine.gaymard@univ-angers.fr

\begin{abstract}
The crisis of the Yellow Vests in France has vastly occupied the media scene since November 2018, and the Great National Debate has just come to an end. The hypothesis can be put forward that the Yellow Vests have become an object of social representation over the months. This exploratory study was performed among a population of young people (average age $=20.5$ ) and took place in two phases: a free associations test to isolate the big themes and a first structure of the social representation $(\mathrm{N}=11)$, and a questionnaire of "calling into question" $(\mathrm{N}=94)$ to confirm the central or peripheral position of the items. The collection of data 4 months after the beginning of the movement does not put forward the first claims such as the spending power and attests for the media coverage of violence. The Chi-Squared Test shows some significant differences between men and women.
\end{abstract}

Keywords: Yellow Vests, Social Representation, Young People, Risky Situation, Media, Gender

\section{Introduction}

Today, who has never heard of the "Yellow Vest crisis"? Inexistent up to a few months ago, this social protest movement is in the news headlines, and no-one can escape this issue whether in the newspapers, on television, on the social networks or even in discussions among friends. This movement which began in November 2018 led to a Great National Debate in March 2019.

When the Yellow Vests define themselves as apolitical, it must not be forgotten that this movement results from dissatisfaction with the internal politics of our country and the feeling of certain classes of an increase in social fractures and inequality. If the trigger of this social crisis seems to be the price of petrol, we can indeed observe a combination of political and social demands such as the increase of the minimum wages, the recourse to a Citizens' Initiative Referendum or the question of retirement or rural isolation for example. Moreover, politicians and trade 
unions have taken up the questions and demands raised by the Yellow Vests. In this climate, it seems interesting to study the social representation that young people have of the Yellow Vests. Even if there exist no studies backed up by figures on the subject, several sources indeed note that young people were absent from the Great National Debates meetings.

\section{The concept of social representation and the object: "Yellow Vests."}

The concept of social representation resulting from the work of Moscovici (1961) defines a set of common sense knowledge articulated with practices. According to Flament and Rouquette (2003), to be an object of social representation, there must be two minimum clauses. First, the object should be a frequent reference in social communication (socio-cognitive salience). Second, there must be common practices relating to the object among the population studied. According to the structural approach originally developed by Abric (1976, 1993) and Flament (1994), the elements of representation are organized around two entities: the central core and the periphery. These two entities have complementary aspects: collective vs. individual, stable vs. changing, homogeneous vs. diversified aspects. The central core corresponds to the elements shared by the group and contains "necessary" elements for the recognition of the object. The periphery is linked to individual practices and includes an essential characteristic which is conditionality; its main function is to protect the central core and absorb contradictions by avoiding a questioning of its meaning.

Originally, the yellow vests are yellow-fluo clothes intended to improve the visibility of any person near a road, in a dangerous situation or on building sites. However, since November 2018 the crisis of "Yellow Vests" could be at the origin of the development of a new object of social representation. Regarding the visibility of the social object and the fact that it is at the center of social issues, it can be seen that the object "Yellow Vests" is a frequent reference in social communications. These last months have been marked by increasing media coverage of the movement of the Yellow Vests, in particular through the social demands that this makes emerge, as well as the economic consequences that it involves. At the end of 2018, the indicators positioned this theme as central in the news. According to Sebbah, Souillard, Smyrnaios, and Thiong-Kay (2018), 731 articles were published on this subject between the $5^{\text {th }}$ and $26^{\text {th }}$ of November, 87 of which only on November 23 rd of 2018 , by taking account ten national daily newspapers alone. It, therefore, seems difficult not to receive information on this movement, explaining an obvious and exacerbated visibility of it in our society. This movement is popular and Yellow Vests are present in every city of the French territory, both in Metropolitan France and overseas. This is not a movement that is limited to the capital, nor a movement only regional.

According to a study published in December 2018 by the Viavoice Institute and relayed by the newspaper Libération, $15 \%$ of respondents said they personally participated in the movement of Yellow Vests during events. In addition, 29\% said they had followed it on a social network or by signing a petition, and finally, $50 \%$ of French people knew "Yellow Vests" in their close entourage (friends, family, colleagues...).

Regarding social issues, the movement of Yellow Vests is based on deep social discontent. Originally linked to the price of gasoline, the claims today are many and varied. According to Baruch, Breteau, Damgé, Durand, and Vaudano (2018), a list composed of some forty varied and heterogeneous demands was sent to the media and to the deputies on November $29^{\text {th }}, 2018$.

Among these claims, a set concerns topics related to spending power (increase of the SMIC (Minimum Wage of Growth)), taxation (return to the ISF (Wealth tax)), the economy, public services, immigration or even the ecology. All these themes carry important social issues. Moreover, faced with the pressure of this movement, The President Emmanuel Macron announced on December $10^{\text {th }}, 2018$, a number of political and social measures such as the increase of the SMIC or the removal of the CSG (The General Social Contribution) for retirees. According to ViaVoice Institute' Preud'homme (2018), the main reasons of this broad social mobilization are due to gasoline price, considered as the main daily life problem for $48 \%$ of French people. But "the current problems of French people are not only economical” (our translation) (Preud'homme, 2018, p.5) because 52\% of citizens 
feel that "the political executives are not representing them nor listen to them" (our translation) (Preud'homme, 2018 , p.5). To answer those claims, a Great Public Debate was launched on January $15^{\text {th }}, 2019$ in order to discuss solutions to improve the daily life of French citizens. According to some media sources, French youth would have overlooked this debate.

As data collection took place in February/March 2019, i.e., 4 months after the start of the movement, the following assumptions are made:

H1: The Yellow Vests are an object of social representation.

$\mathrm{H} 2$ : The central elements of the representation are constituted around elements reflecting a situation of violence. This hypothesis aims to verify that the crisis of Yellow Vests that has taken place a few months ago has evolved into a representation linked to scenes of violence widely spread in the media.

\section{Method}

\subsection{Target population and characteristics}

There are several reasons for choosing a youth population for this research. The first is that since the 1990s, youth abstention has been steadily increasing, reaching 64\% in the last regional elections (Revault d'Allones, 2019). Indeed, "young people who vote are in the minority; if we count the abstainers and those who are not registered on the electoral lists, only a small half of the young people of voting age go to the polls" (our translation) (Muxel, 2001, p.42).

According to Muxel (2001), the increase in abstentionism and the white vote or the vote for extremes are signs of discontent, a form of protest against the political world. If we are interested in polls conducted after the first round of presidential elections in 2017 and published in Le Figaro by Quinault-Maupoil (2017), according to the BVA institute, 18-24 year olds voted Jean-Luc Mélenchon up to 27\% and Marine Le Pen, as well as Emmanuel Macron up to $21 \%$. If we are interested in the data published by IPSOS, this age group would have mainly voted for JeanLuc Mélenchon (30\%) before Marine Le Pen (21\%). Given these votes, we could conclude that there is some protest against the political world in the youth population. We can note also, a certain similarity of vote with the Yellow Vests, since according to the study conducted with 526 Yellow Vests throughout France, by the collective "Critical Quantity" in 2018 and coordinated by Yann Le Lann, senior lecturer in sociology at the University of Lille, the results on the presidential votes of 2017 show that Marine Le Pen and Jean-Luc Mélenchon are both leading with $20 \%$ of the vote. The other reason for choosing young people is that it is a population in which political issues have a strong influence since it is at this age that one acquires the right to vote.

In this research, 11 young people were first subjected to preliminary testing of free associations. Then 94 subjects made up of 38 men (40.4\% of this sample) and 56 women (59.6) completed a questionnaire. Those young people come from all over France. The average age of the participants group is about 20.45 years old $(\mathrm{SD}=1.67)$, (men: 20.42 years old $(\mathrm{SD}=1.35)$; women: 20.48 years old $(\mathrm{SD}=1.87)$ ). Most of the sample is made up of students, $58.5 \%$ of the young people live in an urban area (41.5\% in a rural area); $93.6 \%$ do not belong to a union $(6.4 \%$ do).

\subsection{Tools}

\subsubsection{The free associations test}

In order to elaborate on the questionnaire of "calling into question" the first phase of free associations was carried out with 11 young people. The free associations test widely used in the studies of social representations allow the content of the social representations to be gathered spontaneously from an inductor. The instruction was the following: "When you hear 'Yellow Vests,' which words or expressions come to mind ?." From this instruction, several items were retained. 


\subsubsection{The Questionnaire of calling into question}

Certain themes arising from the free associations phase were called into question. This technique proposed by Moliner (1989) allows the centrality of the elements to be tested and rests on the principle of the double negative. Knowing that the central elements are necessary to recognize the object, the elements of the representation are called into question with this principle. If the respondents do not recognize the object when an element is questioned it means that it is a central element; if the respondents still recognize the object after its being questioned, it means that it is a peripheral element. This method has been used with a variety of formulations and scales of response. In this study, we adopted a formulation already used for another object (Dany and Apostolidis, 2007). The formulation is the following: "Can it be said of a demonstrator (ambiguous object) who.... (followed by one of the 10 items retained in its negative form which corresponds to the first negative) that he or she is a Yellow Vest (object of social representation studied)"?

We chose a scale of response in 5 points ranging from 1 (He or she is certainly not a Yellow Vest) to 5 (He or she is very certainly a Yellow Vest) with a median response (I do not know). If the respondent does not agree it is the second negative of the model. The results lead to levels of refutation; the highest confirm the centrality of the elements.

The data was gathered through a campaign of messages via social networks Facebook. The questionnaire posted was carried out by means of the application of Google Form.

\subsection{Analysis strategies}

The analysis of free associations is based on the prototypical method. This method rests on the cross-checking between the frequency of terms and the average rank of appearance. The "Vergès" software (2005) allows to identify the 4 zones structuring the social representation: the central core with the words more frequent and given in the first ranks; the first periphery, which includes either the most frequent words given in the last ranks, or the least frequent words given in the first ranks; the second periphery includes the words infrequent and given in the last ranks. This method has been widely used near different populations to describe the structure of social representation (e.g., Gaymard, 2014b ; Gaymard \& Bordarie, 2015; Gaymard \& Engelmann, 2016; Gaymard \& Joly, 2013).

Concerning the "calling into question," we have grouped the levels in the following way: 1 and 2 (it is not a Yellow Vest); 3 (I do not know); steps 4 and 5 (it's a Yellow Vest). These groupings make it possible to obtain the refutation percentage (steps 1 and 2). When it is high, it means that when the element is implicated, the object "Yellow Vest" is no longer recognized; the element is, therefore, necessary and considered to be central. Chi-square tests were performed to compare frequencies by gender and place of residence.

\section{Results}

\subsection{The free associations}

The participants having almost all given 5 words, this makes it possible to calculate an average rank at 2.5; up to this threshold, it is considered that the given terms are in the first ranks of appearance and beyond this threshold, the terms are part of the last ranks of appearance. Regarding the frequency of the terms and given the small sample, the high threshold was set at $27 \%$; words or expressions given at least 3 times are considered frequent, and below this threshold, they are part of a low frequency. The table extracted from the Vergès software isolates as central elements during this first stage: "blocking roundabouts" and "social classes / class struggles." It can be seen that the element "spending power" appears in the second periphery (Table 1). 
Table 1: The social representation of the Yellow Vests among young people (preliminary phase).

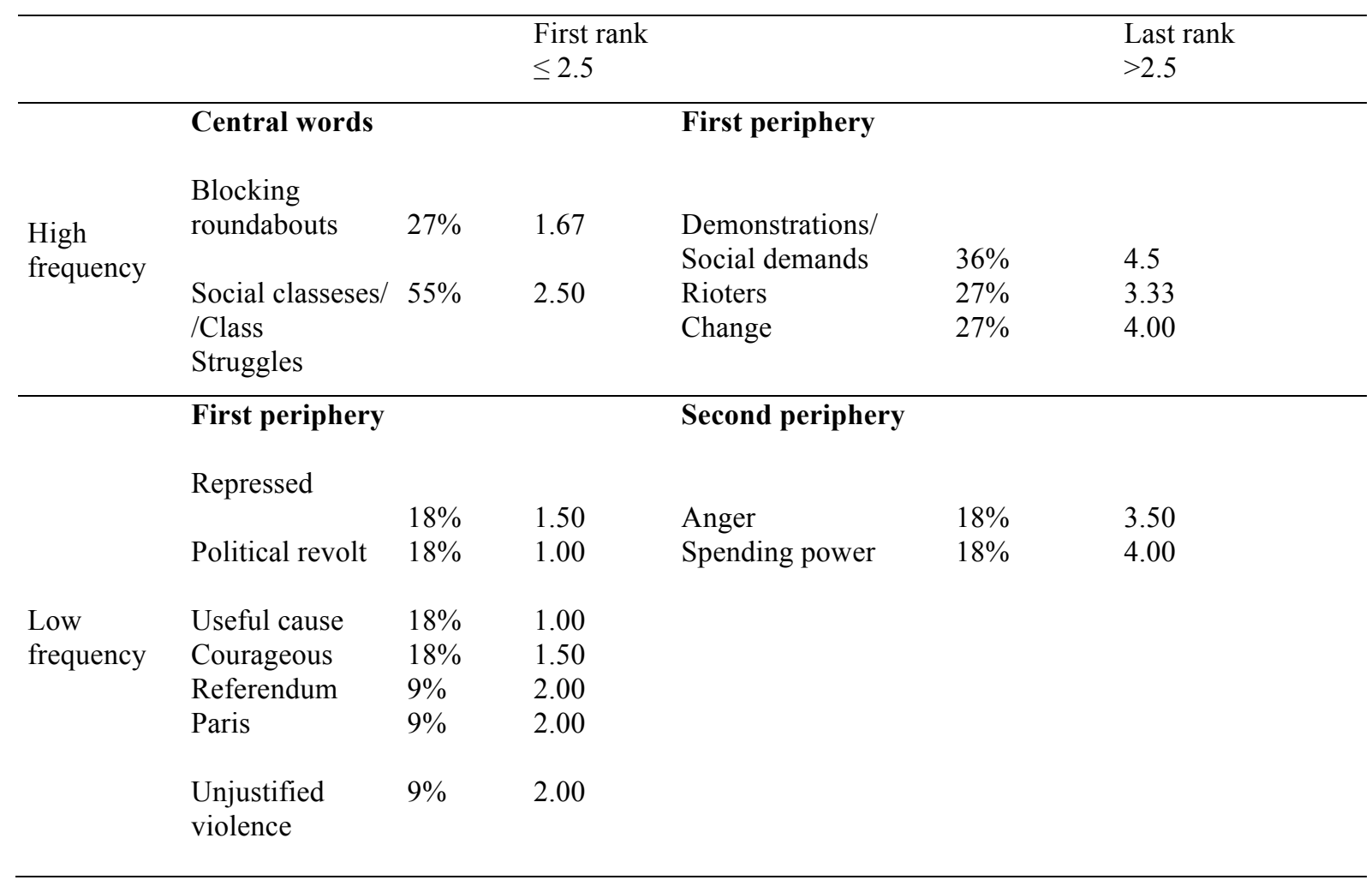

\subsection{The "calling into question."}

From this collection of associations, 10 elements appearing either in the central core or in the first periphery have been tested. Given the small size of the first step, the selection of certain elements cannot be based on a data systematic analysis. If one retains the usual thresholds of refutation to consider that an element is central or not (Flament \& Rouquette, 2003), it emerges from this second stage that the central elements are "courageous," "repressed" and "unjustified violence "(Table 2).

Table 2: Results to the "calling into question" (decreasing ranking of the refutation rate)

\begin{tabular}{|c|c|c|c|}
\hline & It is a Yellow Vest & I do not know & It is not a Yellow Vest \\
\hline $\begin{array}{l}\text { "Can it be said of a } \\
\text { demonstrator who is not } \\
\text { courageous that he or she } \\
\text { is a Yellow Vest"? }\end{array}$ & $5(5.2 \%)$ & $12(12.8 \%)$ & $77(82 \%)$ (central) \\
\hline ...who is not repressed... & $11(11.7 \%)$ & $11(11.7 \%)$ & $72(76.6 \%)$ (central) \\
\hline $\begin{array}{l}\text {...who does not face to } \\
\text { unjustified violence ... }\end{array}$ & $12(12.8 \%)$ & $11(11.7 \%)$ & $71(75.5 \%)$ (central) \\
\hline $\begin{array}{l}\text {... who does not block the } \\
\text { roads... }\end{array}$ & $15(16 \%)$ & $11(11.7 \%)$ & $68(72.3 \%)$ \\
\hline $\begin{array}{l}\text {...who does not defend a } \\
\text { useful cause... }\end{array}$ & $11(11.7 \%)$ & $16(17 \%)$ & $67(71.3 \%)$ \\
\hline $\begin{array}{l}\text {...who does not manifest } \\
\text { for a referendum... }\end{array}$ & $11(11.7 \%)$ & $18(19.15 \%)$ & $65(69.15 \%)$ \\
\hline $\begin{array}{l}\ldots \text { who does not manifest } \\
\text { for a political cause... }\end{array}$ & $16(17 \%)$ & $14(14.9 \%)$ & $64(68.1 \%)$ \\
\hline $\begin{array}{l}\text {... who does not block the } \\
\text { roundabouts... }\end{array}$ & $19(20.2 \%)$ & $12(12.8 \%)$ & $63(67 \%)$ \\
\hline $\begin{array}{l}\ldots \text { who does not invest in } \\
\text { the class struggle... }\end{array}$ & $14(14.9 \%)$ & $17(18.1 \%)$ & $63(67 \%)$ \\
\hline
\end{tabular}




\begin{tabular}{|c|c|c|c|}
\hline $\begin{array}{l}\text {... who does not manifest } \\
\text { in Paris... }\end{array}$ & $15(16 \%)$ & $25(26.6 \%)$ & $54(57.4 \%)$ \\
\hline
\end{tabular}

The Chi2 tests show some significant differences, not according to the place of residence (urban vs. rural) but according to gender. These differences concern the items "unjustified violence," "useful cause" and "referendum"; a trend toward significance is observed with the item "repressed" (Table 3).

Table 3: Chi-squared Test (Pearson) with gender and place of residence

\begin{tabular}{lcccc}
\hline & \multicolumn{2}{c}{ Gender } & \multicolumn{2}{c}{ Place of residence } \\
\hline & Chi2 value & P & Chi2 value & P \\
\hline Courageous & 1.496 & .473 & 1.309 & .520 \\
\hline Repressed & 5.398 & $.067^{\mathrm{b}}$ & 3.307 & .191 \\
\hline Unjustified Violence & 10.542 & $\mathbf{. 0 0 5}^{\mathrm{a}}$ & 1.113 & .573 \\
\hline block the roads & .131 & .936 & .520 & .771 \\
\hline Useful cause & 6.420 & $\mathbf{. 0 4 0}$ & 4.110 & .128 \\
\hline referendum & 6.065 & $\mathbf{. 0 4 8}$ & 2.096 & .351 \\
\hline Political cause & 2.789 & .248 & .837 & .558 \\
\hline Block roundabouts & 3.735 & .154 & 1.175 & .994 \\
\hline Class struggle & .470 & .791 & .013 & .451 \\
\hline Manifest in Paris & .879 & .644 & 1.592 & \\
\hline
\end{tabular}

\footnotetext{
${ }^{\text {a }}$ In bold, significant differences
}

${ }^{\mathrm{b}}$ Trend toward significance

When we look in detail at the frequency's distributions, concerning the 3 significant items and the one with a trend toward significance, roughly they have all the same profile: the women's refutation rate is higher, and there are more men who continue to recognize the object (see for example the illustration of the item "unjustified violence" (fig 1)). Nevertheless, among these items two are central ("repressed," "unjustified violence" see Table 2) because they have a refutation rate globally higher, the 2 other items are peripheral ("useful cause"; "referendum").

Figure 1: Can it be said of a demonstrator who does not face unjustified violence that he or she is a Yellow Vest? (Percentages)

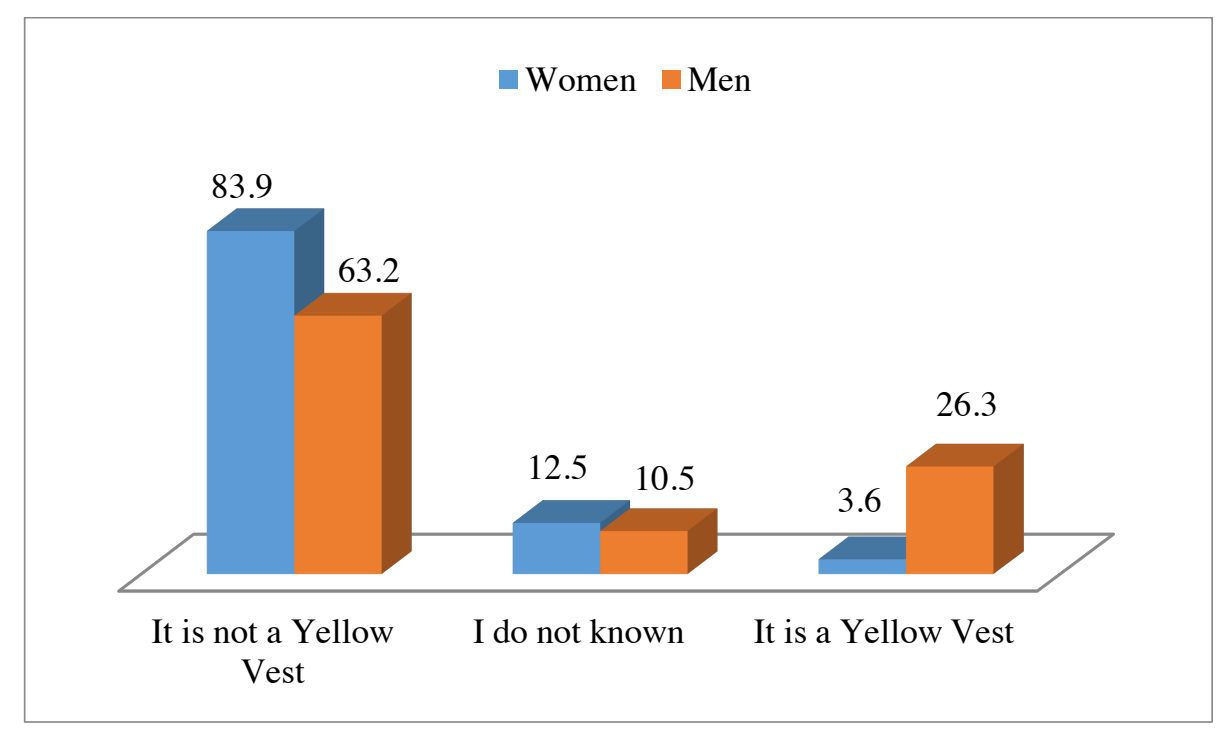




\section{Discussion}

The Yellow Vests crisis started in November 2018, and five months later, it is still part of the news. Today, 50\% of French people still express support or sympathy for the Yellow Vests ${ }^{1}$. The recent character of this movement explains the lack of scientific publication in the Human and Social Sciences on this subject.

This study in the field of social representations (Abric, 1993; Flament 1994; Gaymard, 2014a) had the objective of validating two hypotheses: one on the Yellow Vests as an object of social representation and the other on the centrality of violence given the news and images conveyed by the media.

The observed results validate these two hypotheses. The Yellow Vests have become over the time an object of social representation. The preliminary phase of this study with the free association method (Vergès, 2005) shows that the social representation is structured around two central elements which are: blocking roundabouts and class struggle. Moreover, it can be seen that the "spending power" element is in the second periphery while it was one of the first claims at the beginning of the movement; this confirms the evolution of it over the months. One might think that if we had collected the characteristic elements of this movement when it was born, the spending power would have been more important.

In order to verify the centrality of the elements, the calling into question method was applied. The results of this second phase by applying the usual limit of the refutation rate (75\%) show that it is elements that appeared as peripheral during the preliminary phase that becomes central. Indeed, when the elements "courageous", "repressed" or "unjustified violence" are questioned, respondents no longer recognize the object of social representation (refutation rates $82 \%, 76.6 \%$, and $75.5 \%$, respectively); we can, therefore, consider that these elements are necessary for the object "Yellow Vests". Conversely, by calling into question the elements "blocking roundabouts" and "class struggle." the refutation rate (67\%) indicate that the Yellow Vest object is still recognized; these elements are therefore peripheral. These new results confirm the evolution of the movement of Yellow Vests over time and validate the second hypothesis. Media images have crystallized the movement of the Yellow Vests around the violence but especially around a perceived injustice because the Yellow Vests are seen as courageous and unjustly repressed. These elements may explain why a part of the population still expresses sympathy for this movement.

Another interesting result of this study is based on Chi2 tests. There is no significant difference depending on the place of residence (Urban vs. rural), however, there are significant differences depending on gender. So, women consider more than men that yellow vests are repressed, face unjustified violence, defend a useful cause and protest for a referendum. This feeling of injustice and revolt is thus more prominent in women. This seems to support analyzes on social networks that highlight themes such as: "Women at the forefront of the revolt of Yellow Vests" (our translation); Beyond the explanations given to their commitment as the fact that they are more affected by economic precariousness, it is interesting to observe in our exploratory sample of young people an increased sensitivity among women. These results confirm that the Yellow Vest crisis represents a particular turning point for women and that they feel it accordingly.

"This is something relatively new, and probably a historic turning point in the history of social struggles. They (the women) were massively on the roundabouts and in the demonstrations. An even newer phenomenon is women of all ages, young and old, who have courageously embarked on subversive action" (our translation) ${ }^{2}$.

Finally, the Yellow Vests crisis that began in November 2018 with the price of petrol has become over time a means of expression, especially for women.

\footnotetext{
${ }^{1} \mathrm{https} / /$ elabe.fr/gilets-jaunes-grand-debat-national-2/

2 Extrait de « Les femmes, la violence policière et les gilets jaunes » (publié sur internet le 25 mars 2019).
} 


\section{References}

Abric, J.C. (1976). Jeux, conflits et représentations sociales. Thèse de doctorat d'Etat, Université de Provence, Aix-en-Provence, France.

Abric, J.C. (1993). Central system, peripheral system: Their functions and role in the dynamics of social representation. Papers on Social Representations, 2(2), 75-78.

Baruch, J., Breteau, P., Damgé, M., Durand, A.-A., \& Vaudano, M. (2018, 4 Décembre). Sur un axe de Mélenchon à Le Pen, où se situent les revendications des «gilets jaunes ». Le Monde. Retrieved from https://www.lemonde.fr/les-decodeurs/article/2018/12/04/sur-un-axe-de-melenchon-a-le-pen-ou-se-situentles-revendications-des-gilets-jaunes_5392592_4355770.html

Dany, L., \& Apostolidis, T. (2007). Approche structurale de la représentation sociale de la drogue : interrogations autour de la technique de mise en cause. Les Cahiers Internationaux de Psychologie Sociale, 73(1), 11-26.

Flament, C. (1994). Aspects périphériques des représentations sociales. In C. Guimelli (Ed.), Structures et transformations des représentations sociales (pp. 85-118). Lausanne: Delachaux et Niestlé.

Flament, C., \& Rouquette, M.L. (2003). Anatomie des idées ordinaires. Paris : Armand Colin.

Gaymard, S. (2014a). The theory of conditionality: an illustration of the place of norms in the field of social thinking. Journal for the Theory of Social Behaviour, 44(2), 229-247. doi: 10.1111/jtsb.12039

Gaymard, S. (2014b). Social representation of work by women and girls with intellectual disabilities. Life Span and Disability, 17(2), 145-173

Gaymard, S., \& Bordarie, J. (2015). The perception of the ideal neighborhood: A preamble to implementation of a "street use code." Social Indicators Research, 120(3), 801-816. doi : 10.1007/s11205-014-0610-1

Gaymard, S., \& Engelmann, W. (2016). Nanotechnologies, risks, and societal concerns. Modern Applied Science, 10(10). doi : 10.5539/mas.v10n10p241

Gaymard, S., \& Joly, P. (2013). La représentation sociale du football chez des jeunes adultes issus d'un milieu social défavorisé. Loisir et Société/ Society and Leisure, 35(2), 263-292.

Moliner P. (1989). Validation expérimentale de l'hypothèse du noyau central des représentations sociales. Bulletin de Psychologie, XLI, 759-762.

Moscovici, S. (1961/76). La psychanalyse, son image et son public. 2nd Ed. Paris: Presses Universitaires de France.

Muxel, A. (2001). Les choix politiques des jeunes à l'épreuve du temps Une enquête longitudinale. Revue Française de Science Politique, 51, 409-430.

Preud'homme, A. (2018). Le baromètre politique. ViaVoice Libération. Retrieved from http://www.institutviavoice.com/wp-content/uploads/2018/11/Le-barom\%C3\%A8tre-politique-Viavoice-Lib\%C3\%A9ration.D\%C3\%A9cembre-2018.pdf

Quinot-Maupoil, T. (2017, 24 Avril). Les jeunes plébiscitent Le Pen et Mélenchon, les cadres votent Macron. Le Figaro. Retrieved from http://www.lefigaro.fr/elections/presidentielles/2017/04/24/3500320170424ARTFIG00110-les-jeunes-plebiscitent-le-pen-et-melenchon-les-cadres-votent-macron.php

Revault d'Allonnes, C. (2019). L'engagement politique chez les jeunes. Retrieved from https://www.partisocialiste.fr/blog/lengagement-politique-chez-les-jeunes/

Sebbah, B., Souillard, N., Smyrnaios, N., \& Thiong-Kay, L. (2018). Les Gilets Jaunes, des cadrages médiatiques aux paroles citoyennes. Toulouse: Université de Toulouse. Retrieved from https://fr.scribd.com/document/394250648/Rapport-Gilets-Jaunes

Vergès, P. (2005). Programme d'analyse des évocations « Evoc ». Version non commercialisée. LAMES-CNRS. 